\title{
山形県向町前森原丽状地について
}

若生達 夫

小国川の一支流絹出川の上流部には，狭長な 扇状地地形があり，1961年4月，2 日間にわたり 現地調査を行なつたので資料として報告する。 当地については, 富田芳郎ふ，侵玲扇状地の 範ちゆ5に入る可能性として，次のように近へ ている。「因みに，日本の東北地方でも、こ の岩石扇状地を思わせるような緩斜面が、川地 内の溪谷上流に見られることがある。例穴ば，

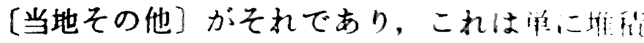
扇状地とするには不適当で, 内部構造はその露 出不良のために的確には断定出来ないが......」

とし, 基盤岩の平滑面の子想と，九の平㳙化 の営力が, 断層璉動などと関漸した河の僋触に 因る可能性」を述ぺておられる'，

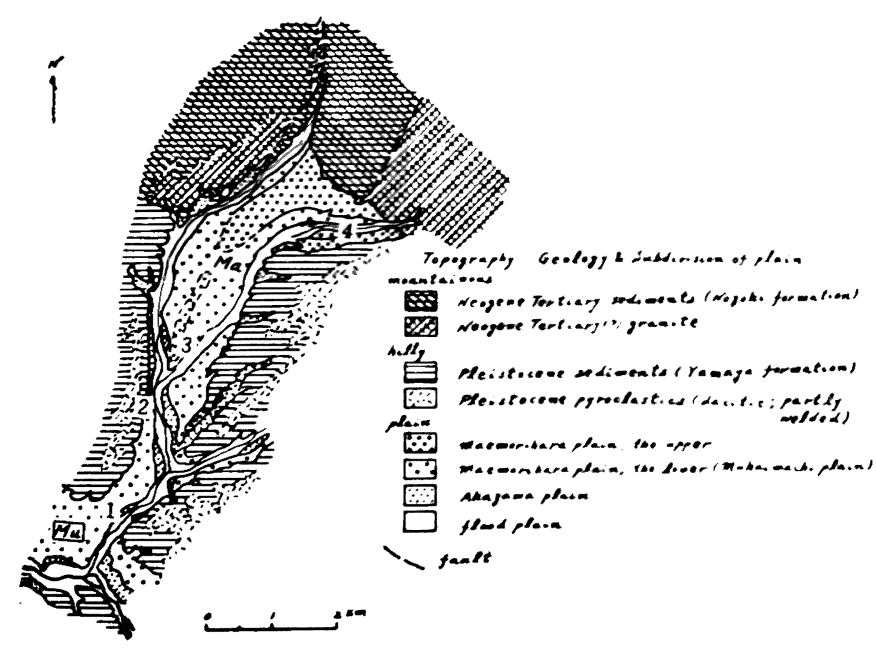

Fig. 1
筆者は，侵蚛緩斜面の形成に関心を持つてお。 ク, 富田先生の云われるこの地についても, 槛 僬を知りたいと思つていた。予想通り, 露頭は 础んどなく，完全ではないが，一钼料として報 告すると共に，いわゆる扇状地について，筆者 の於卟で，僅かの訯を行ないたい。

\section{I. 地形・地誓の大略}

山形紧打の湖から，次の上5に藏える Fig 1)。

山地：中新址及位層と积三紀花崗岩からなつ ている。前者は, 化游岩を基盤とし, 緑色凝灰 出 である。後者は、新第三紀に，前者に刘して岩 脈状に贯人したと見られる ${ }^{3}$ 石英花㴊内緑岩で あつて, 一部, 断層で接している。

丘稜：洪積世の山屋層と石英安山 岩質火山确㞒物からなつている。前 者は軟い㗭岩であり，凝炭岩・同質 シルト筂を挾在している。時に偽層 理の発䞗が著しい。後者は, 一部は 熔結凝灭嵓となり，他は，いわゆる シラス状になつている。

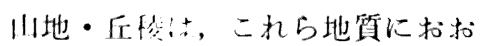
よそ相仙している。な!，Fig. 1の 地質は，篗者の资料も分之，20万分 の 1 地澌龱か 55 万分の 1 地形図に 転写したものであり，湒美は大きい にちがいない。しかし，哧告では 文障のない程度のものである。

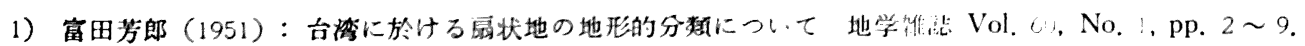

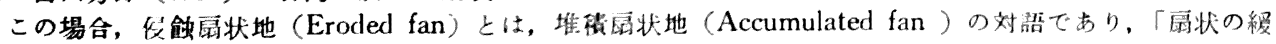

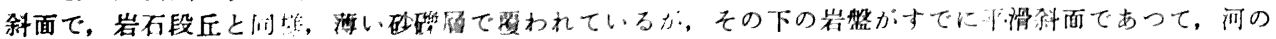

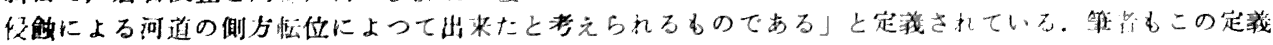

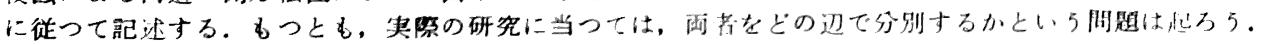
しかし，別の表現をとるならば、これが静水中の normal sedimentation or deposition と河川の陫橉との ちがいであつて,川の場台には怕に堆积と云つても, aggradationの場台と, degradation の過程中および

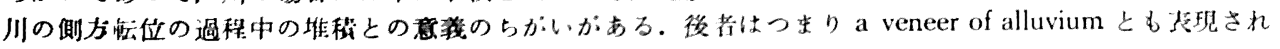
ているものである.

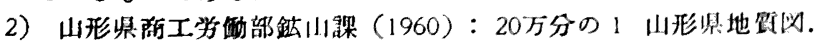

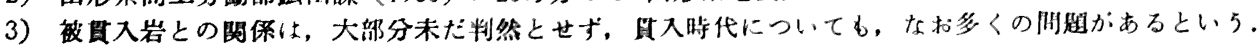


低地：地質図には，当然のことながら，扣抒 まかに示されているにすぎない。この部分が筆 者の報告の中心なので，項を改めて記述する。 地質図では，前森原それ自身，山屋層で满成さ れているよ5に図示されているが,これは，後 迹のように，誤であることだけを述べて拈く。

\section{II. 低地の区分およひ構造}

低地を四区分し，前森原上面・同下面（=向 町面）・赤沢面扣よび現沖積面とした。その分 布・梇造は Fig. 1 およびFig. 2 に小した。

1. 前森原上面㧍よび 下面（向町面）

絹出川は，向町の北䄪 $3 \mathrm{~km}$ で二股に分机るが, 西方のものが清水の片。 束方のものが水無沢と云 われる。上地の人涬の云 5 前森原とは，この合流 点以北, 両河流に摤まれ た，秋長な扇状地形態を とる部分である゙。

ここでは，主体は二面 に区分できる。それらの 間の崖は,上流側で明瞅

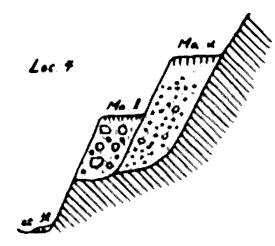

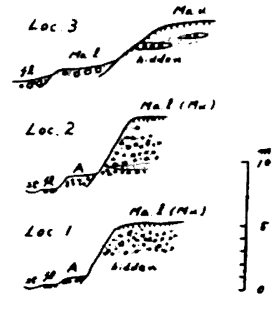

Fig. 2 であるが，下流に向つては，次第に仿明㖹にな

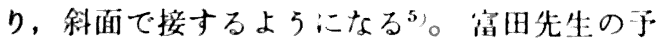

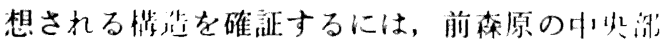
を中心として，多数の地点で融を見ることが 眥ましい。しかし，中央部では全く不间佗であ り，水無沢を执んでその奶落，Loc４で，归

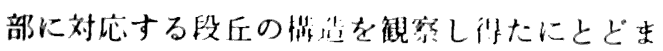
る (Figs. $3 \& 4$ )。

上面と下面とを比較与ると，引々の脽程物基 底の高度差は僅かであり, 地表の高度、は，は

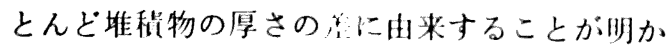
である。

上面をなす堆积物は、シルト・们・䂺であり，

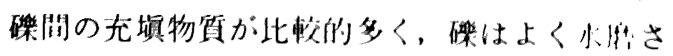
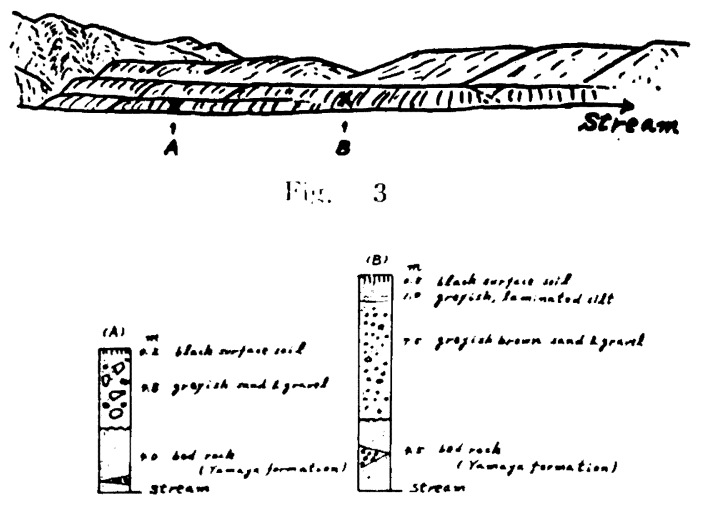

Fig. 4

れ，稀に垎 $20 \mathrm{~cm}$ に洼するものがあるが，多く は $2 \cdot 3 \mathrm{~cm}$ であり，粒経の揃つていることが特徵 であう。これに反し，下面のそれは， sortingが

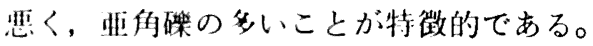

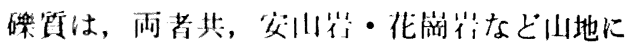
机湆をもつものの他，川屋居に山来するらしい より所恀した磷も又ら机る。しかし，特に下面

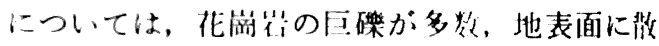
在していることが特徽的である。

上面汢, 前过の如く, 前标原の南端で, 下面 と殆んど一致し，ょり下流側では分布を欠く。 下面は下流に向つて延び，向町の载る段丘とな

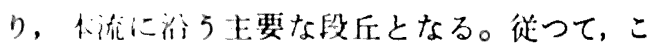

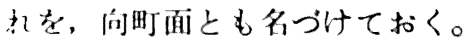

な扰，上下雨面の晴代的関保であるが, 前述 のよ5に，堆积物の基底高度からすれば，地形

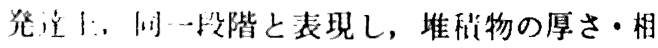
(facies) から，phase の違い，と云つてよさそ らである。たた，嘫が地表にまで散在している のは下面に特微的であり，堆程相の革いるそ の原川の一つかも知れないか，照色表土の厚さ も，上面に少く，下面に薄い一般的傾向がある ので，絶対的には，比較的長い時間間隚がある のかも知れないて。

2. 小沈面

前怕下泊より低く，桨通の淇水では冠水し

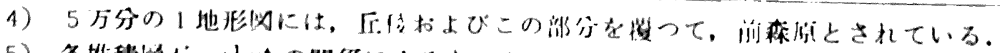

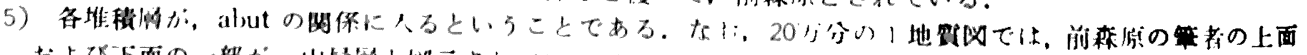

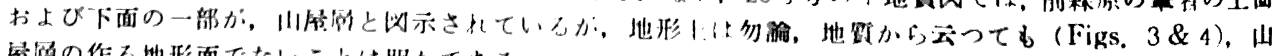
展四の作る地形面でないことは明かである。

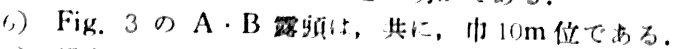

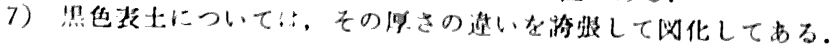


ない部分を，前森原にある部落名からこう名 づけた。本報告の大きな部分ではないので，説 明は割愛する。

\section{3. 現沖積面}

白色の花崗岩啋の卓越することが特徵であ る。特に水無沢は，名の通り，Loc. 4 より僅か 下流で伏流となり，清水の沢と合流する直前で 地表流になるがッ，その間は，ょく水然された

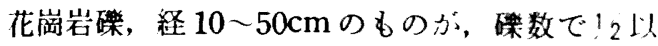
上を占めている。

\section{III. 各面の相互関係}

横断図で知られる通り，絹出川の下流すなわ ち本流小国川との合流点に近つ汁ば，前桥原下 面（向町面）は，河流・現沖䅡面・赤沢面と， やや等しい比高で配置しており，より上流部 Loc. 3 附近では, 前森原下面堆䅡物は, 現沖䅡 面喽層と abut の関係にある。更に上流 Loc. 4 に至れれば前森原上・下両面共，下流にがるよ りもより大きな比高で配㯰するよ5になり，し かも, 基盤も現われてくる。前森原下面（向町 面）の段丘崖が Loc. 2 ですべて堆積物からな る他, 下流部での構造は, 確認し得ないが,お そらくは，上流部とさして変らない堆積物の厚 さしかもつていないのであろら。これは，流 沿い向町面の消極的な資料からの堆恣てある。

\section{IV. 要 的}

1. 構造渾動との関保：低地の各地形面の槛 造からすれば，すべて，叮成坆丘と云つてよか ろう。上流部では，隆㻎および，おそらくは河 流の grade の型とも関連し, 古期の段丘が下流 においてょりも，より高位に位㯰しているのた と考えられる。

構造的な点では，これ位しか云える兮料はな く，ょり広域の調植が必要とされる。清水の沢 は抢そらく断層線谷であり，前森原の北西楾の 山地前面は，その延長上にある。また，前森原 北東の山地前面には, kerncol ・ kerndut 地形が みられる。これら山地前面か，断層に関係する ものとしても，この斬動の主要な時期は, 山屋 層堆積時の堆積盆を决定した当時のものである 可能性が大きい。たた，この地の地学的位㯰か
らすれば，常識的にはなお active であるにち がいない，と云えよう。

2 . 前森原の形態と成田：前森原は, 山屋層 という, 山地にくらべれば, 極めて軟弱な地層 を切つて容易に形成されたと思われる。まつは

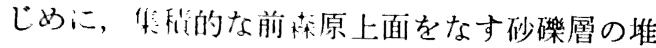
皘があり，その该，前森原下面をな与，より集

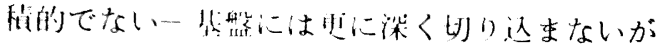

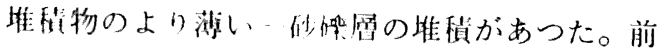

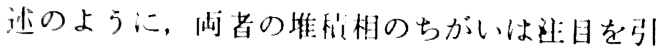
くが，钼察した路到の数が少ないので，䅡極的 こはての門由を云えない。しかし，総体的に云

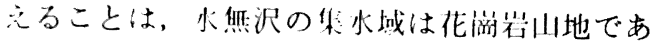
り，歹，ての頂上は「否岳」と称されている 所であつて, ここからの多苗の化崗岩磻の供給 は, 测流の例方移動一側鳋に, 前記山屋層の分 布と共に広い地形面の生成に资していよ5。

3. 類似する扇状地について：以上のことよ り, 高森原は巾広い岩石段斥, あるいは舌状の 侵触扇状地と云える。本邦の扇状地をみると， その堆皘物の厚いもの（堆積扇状地）と薄いも の（侵触扇状地）があり，後者は，その地形の 平面形からは扇状地ではあるが, 堆積物が薄く 堆皘物の基瓜面そのものが，地表形態に反映し

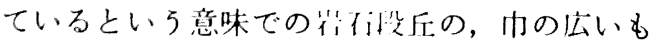
のと云える。いつれ，文献学的にも総括的に論

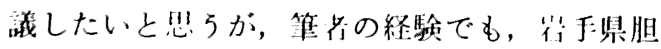
沢郡の六原的状地，次の機会に報留与る予定の

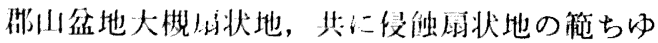
5に人れるべきものである。たた，古期の河流 堆䅡物上に唯积しているために，往々，その総

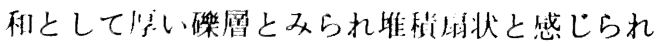
ることが多いよらである。典型例として，教科 清によく引用されている忪本盆地の扇状地も, 扇状の地表形態を表現しているのは，実は，薄 い新期の上層堆积物であると閆いている。

従つて, 扇状地權成層の時代的関係に注意す れば，伩蚛扇状地が比洨的多いようであり，ひ いては盆地の性状区分に，より有効な基準をも たらして得ると思われる。

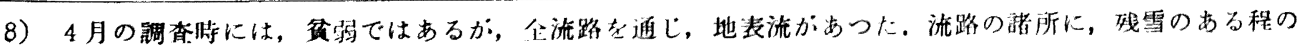
時期だつたためであろら。 


\title{
On the Geomorphological Structure of the Maemorihara Plain, Yamagata Prefecture.
}

\author{
Tatsuo Wakô
}

Prof. T. Tomita (1951) referred to the Maemorihara plain when he discussed on the structure of alluvial fans in Taiwan (Formosa). He stated "there may be eroded fans even in the Main Island of Japan, such as those in arid regions. Probably it in hard to confirm the possibility of the formation of eroded fans in the Main Island of Japan simply because of the deficiency of finding the outcrops showing the structure of alluvial fans". and treated the Maemorihara Phain as an exsample which has the possibility of such structure, Although the present writer does not necessarily agree with his opinion, the writer studied Maemorihara Plain recently to analyse the structure of this tongue-shaped plain, and concluded as follows ;

1. Maemorihara Plain is composed of two portions with different levels, the upper and the lower Fins. $1 \& 3$ ).

2. The heights of the basements of deposits that constitute the upper and the lower levels are approximatcly same, while the thicknesses of the deposits are different, resulting in the diffecence of the levels Fig. 4).

3. The deposits that constitute the upper level are sorted well and those of the lower level are sorted less. This is caused by the epicyclic changes in the development of the stream system.

4. The upper and the lower levels were built as terraces of erosion in the present shape of an elongated fan, that is in the tongue shape.

5. Factors that contibuted to the formation of such a shape are the distribution of loose Pleistocene sediments and the shifting of the courses of the stream loaded with a large amount of breccia produced from the granitic mountain.

The writer has observed several fans which suggested him of the structure such as this, and thinks that not a few of the fans in Japan may be of the erosional origin rather than accumulated one.

Fig. 1 : Map showing the topography and fecology in the vicinity of Mukaimachi, Yamagata Prefecture. Mu : Mukai-machi, Ma : Maemorihara

$1 \sim 4$ : Locality numbers of cross-sections shown in Fig :2.

Fig. 2 : Cross sections showing the relations between each plain terrace: The sites of each section are shown in Fig. 1.

Fig. 3 : View of the mountain, hill, and two terraces at Locality 4, sketched from the opposite bank. A. B : see Fig. 4.

Fig. 4 : Geological columns showing the structures of the lower Maemorilhara plain (B) and that of the upper one $A$, respectively, at locality 4. 